\title{
Combining ability and gene action studies for horticultural traits in cowpea: A review
}

\author{
AK Verma, D Sharma, Gangadhara K, AK Mehta \& P Singh
}

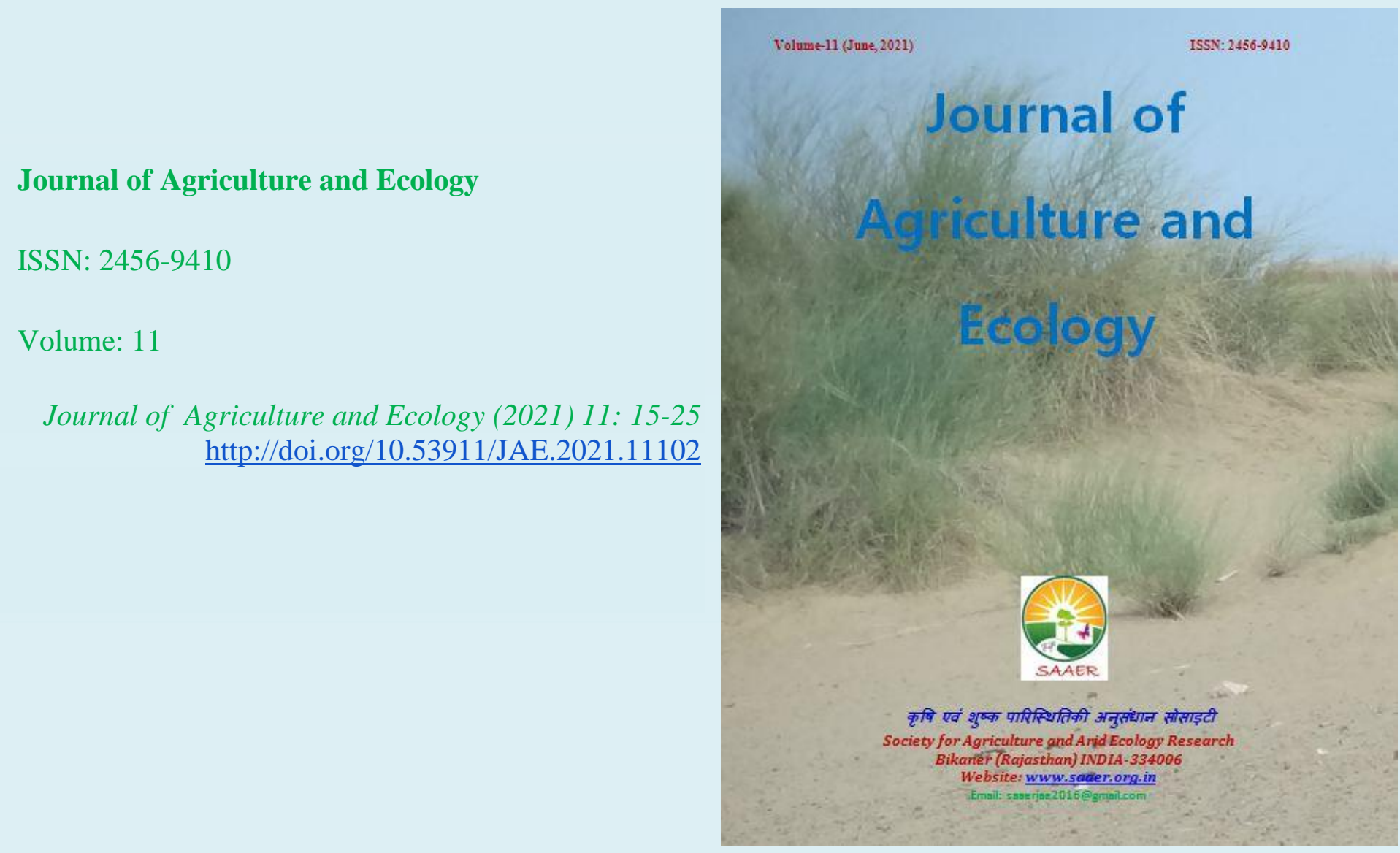




\title{
Combining ability and gene action studies for horticultural traits in cowpea:
}

\section{A review}

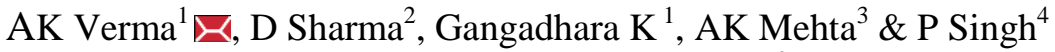 \\ ${ }^{1}$ ICAR-Central Institute for Arid Horticulture, Bikaner, Rajasthan, ${ }^{2}$ Department of Vegetable Science, \\ IGKV, Raipur, Chhattisgarh, ${ }^{3}$ Department of Plant Breeding and Genetics, JNKVV, Jabalpur, Madhya \\ Pradesh, ${ }^{4}$ Department of Horticulture, RVSKVV, Gwalior, Madhya Pradesh \\ $\square$ Corresponding author: AK Verma,E-mail: ajayhorti19@gmail.com
}

\section{Article Info}

Article history

Received: 10 March 2021

Accepted: 05 June 2021

Available online: 30 June 2021

Key Words: Combining ability, cowpea, gene action, horticultural traits, Vigna unguiculata.

\begin{abstract}
Identification of most suitable parents is one of the most important requirements in any crop improvement approach for development of elite lines/genotypes. The combining ability analysis helps to choose the best parents for crop improvement programmes for desirable traits. The attraction of combining ability is that it provides a reasonable basis for forecasting the performance of yet untested crosses but yet makes no assumptions genetically. This technique helps to choose the best hybrid combinations in terms of superiority over the parents and reveals the type of gene action associated in the inheritance of different characters. Therefore, combining ability study has been the most important and efficient tool for identifying the desirable parents for a crop improvement programme. The knowledge and information about the heritability of yield and its component traits in cowpea can be explored to develop high yielding cowpea varieties with wider adaptability as climate resilient approach to extenuate climate change through appropriate conventional and advance breeding methods. This review will be useful in understanding the opportunities offered by combining ability and gene action studies in cowpea (Vigna unguiculata $\mathrm{L}$. Walp) for improving productivity and various horticultural traits.
\end{abstract}

Copyright (C2021 Verma et al., This is an open access article published under the terms of the Creative Commons Attribution License, which permits unrestricted use, distribution, and reproduction in any medium, provided the original work is properly cited.

Preferred citation: Verma AK, Sharma D, Gangadhara K, Mehta AK \& Singh P. 2021. Combining ability and gene action studies for horticultural traits in cowpea: A review. Journal of Agriculture and Ecology, 11: 15-25; http://doi.org/10.53911/JAE.2021.11102.

\section{Introduction}

The cowpea Vigna unguiculata (L.) Walp. is an important legume vegetable and an important component of cropping systems. Cowpea is cultivated for the immature green pods and dry seeds which are consumed as vegetable and pulse, respectively. Besides, it is also used as green manure and fodder crop. Cowpea is also known by various vernacular names as yard-long bean, snake bean and asparagus bean and many other local names as Lobia (Hindi), Barbati (Bengali), Urohi (Assami), Sonta (Garhwali), Chavati (Marathi), Alasande (Kannada) and Manpayar 
(Malayalam). It belongs to the family Leguminosae (fabaceae) and has chromosome number, $2 \mathrm{n}=22$ (Steele, 1976). India is designated as the main Centre of Origin (Vavilov, 1939). There are five sub species There are five subspecies of vegetable cowpea viz. unguiculata, sesquipedalis and cylindrica which are designated as cultivated and dekindtiana and mensenensis which are designated as wild (Verdcourt 1970). Cowpea is referred as a promising climate resilient legume because of its protein content, ability to fix atmospheric nitrogen, tolerate climatic and edaphic stresses and hence, it is cultivated both during rainy and summer seasons. It is rich in nutritive value. Its edible pods are good source of high-quality protein $(3.5 \mathrm{~g}), \mathrm{Ca}$ (72.0 mg, P (59.0 mg), Fe (2.5 mg), carotene (564.0 mg) and vitamin 'C' $(24.0 \mathrm{mg})$ per 100 $\mathrm{g}$ (Gopalan et al. 1982). India is the second highest vegetable producer in the world. Total production of vegetable in India is 184.39 million tonnes from an area of 10.25 million hectares and beans cover an area of 0.22 million hectares with the total production of 2.27 million tonnes (Anonymous 2018; Balai et al. 2017).

There are many challenges in cowpea cultivation such as low yield, tolerance to biotic and abiotic stresses etc. due to unavailability of region-specific improved genotype/variety which can suit well in different cropping systems and have wider adaptability. Though the country has vast genetic variability for various traits, productivity for green pod yield has not been achieved to the highest level. Hence, the development of short duration, bushy and photo-thermo insensitive varieties/genotypes with high yield potential and quality are the main objectives for improvement in this crop.

Genetic diversity is very important for any crop improvement programme. The larger the genetic diversity in the crop is, more the opportunity will be for identification of the suitable parents for hybridization in the crop. Further, the genetics of the yield and its contributing traits needs to be well elucidated. In a crop like cowpea, which is an autogamy by pollination, hybridization between selected parents is used to create variability. The selection of parents plays a crucial role in success of hybridization and studies on combining ability and gene action helps to choose superior parents and cross combinations (Priya et al. 2018) as it estimates the breeding value of parental lines to produce hybrids (Owusu et. al. 2018). The gca (general combination ability) denotes to additive gene action and is used to determine the performance of parents in general terms while (specific combining ability) is determined by non-additive or dominant gene action and is used to indicate the hybrid performance in specific terms. These variance components are used to determine the gene action and to estimate the genetic prepotency of parents in hybrid combinations. Matting designs such as Diallel (Griffing 1956) and line $\times$ tester (Kempthorne 1956) provide reliable information about the combining ability of parents and their cross combinations (Owusu et. al. 2018; Samadia \& Haldhar 2019).

Thus, it becomes essential to characterize the genetic nature and extent of heritability of various yield and its components and assess potential of parents in hybrid combinations as well. Combining 
ability studies is such a tool that provides information in this regard. The analysis of general and specific combining ability assists in selection of promising parents and specific cross combinations, respectively. The knowledge gained through the combining ability and gene action studies would help to identify superior parents, suitable breeding approaches and to select the promising segregants from the $F_{2}$ and later generations for improvement of yield and various horticultural traits of cowpea. Keeping the above under consideration, the present review will be helpful to estimate the general and specific combining ability of parents and hybrids, respectively and to determine gene action and genetic relationship among pod yield and its contributing attributes.

Gene action: Knowledge of genetic architecture governing the inheritance of different yield contributing components provides a platform to plan/initiate a systematic crop improvement approach and assist in identification of the appropriate breeding technique for improving the characters of economic importance. Several researchers have studied the genetics of different plant growth, yield and quality attributes in cowpea. The brief review of genetic studies relevant to the gene action governing pod yield and its contributing traits in cowpea are presented below:

Shashibhushan \& Chaudhari (2000) carried out an experiment to study the combining ability for various traits in cowpea and observed that both GCA and SCA variances were highly significant for all the traits. Their findings indicated the involvement of additive gene action for all the traits as the magnitude of GCA variances was higher than the SCA variances. The parents viz. GC 3, FTC 27, GC 9203, HC 94-2 and V 585 were the best general combiners for seed yield and most of the characters which should be exploited in hybridization programme. Dokashi \& Mohamed (2003) evaluated $F_{1 s}$ originating from $5 \times 5$ half-diallel cross and observed the involvement of both additive and non-additive gene actions in all traits. The magnitude of GCA) was higher than the magnitude SCA and partial to overdominance expression was reported for all traits. Simple additive-dominance model was adequate to depict the variation for characters like flowering time, pod length, number of seeds per pod and pod weight per plant along with high broad and narrow sense heritability. The findings of their study indicated that the seed yield, seed size and earliness could be improved through selection within the segregating population of studied crosses which were found superior for the above traits. Singh et al. (2004) conducted the hybridization programmes among the parents viz. Sel. 2-1, Sel. 2-2, Arka Garima, Var. 263, Sel. 11, IHR Sel. 16, Pusa Komal and BC 244002 including reciprocals to study the gene action. The study indicated the involvement of significant additive genetic components of variation for all the traits studied except for the no. of pods per plant. The overdominance component of variation was greater than the additive component of variation and was significant for all the characters studied except pod length. Heritability estimates were positive and significant for plant height, primary branches per plant, pod length, 100 seed weight and pods per plant. Kalubowila 
(2006) conducted a study to estimate heterosis, gene action and combining ability in 12 different traits in cowpea through line $\mathrm{x}$ tester analysis involving three lines and 16 testers. The 19 parents and their 48 hybrids were grown in RBD design with three replications at Botany Garden, UAS, Dharwad during Kharif season. The analysis of variance exhibited significant difference among the genotypes for all the characters, except number of branches and number of seeds per pod, indicating the presence of considerable genetic variability among parents. The combining ability study indicated that variances were significant for all traits examined, except number of main branches per plant, seeds per pod and pod length and the dominant component was greater in magnitude than additive component suggesting the importance of non-additive gene action. Patel et al. (2008) carried out an study to determine the nature of gene action and importance of additive and non-additive gene action for various plant growth and yield attributes and protein content. The study revealed over dominance component of variation for characters like days to $50 \%$ flowering, branches per plant, pods per plant, seeds per pod and pod yield and dominance variance for protein content. Rashwan (2010) carried out an experiment at South Valley University, Experimental Farm to estimate of some genetic parameters to understand the heritability of yield and its components of crosses (Azmerly x IT 82C-16 and Azmerly x IT 81D-1137) in cowpea. The results revealed that most of the characters had dominance gene action in both the crosses however, the additive gene effects were also observed for days to flowering, number of pods per plant in the (cross 1), seeds weight per plant, total seed yield in the (cross 2) indicating the importance of breeding approach based on the type of gene action involved for genetic improvement of pod yield and its associated traits in cowpea. Patel et al. (2013) carried out a study in half diallel matting design with twelve parents in cowpea to study the combining ability. Significant differences among the parents was reported for all the characters indicating the involvement of dominance genetic variance for all the characters. Okunlola (2014) carried out an experiment at the College of Plant Science Screen House, FUNAAB. Results obtained showed that plant height at six weeks was due to additive gene effect, number of days from planting to first flower was due to non-additive effect, Pod length was also due to additive gene effect while both seed per pod and 100-seed weight were mainly due to non-additive gene effect.

Combining ability: Kalubowila (2006) conducted a study to estimate heterosis, combining ability and gene action in 12 different characters in Vigna unguiculata through line $\mathrm{x}$ tester matting design having three lines and sixteen testers. The parent $\mathrm{V}$ 118 among lines and IC 202784, IC 202782 and Goa local among testers had significant and positive GCA effects for yield and its contributing traits. Singh et al. (2006) studied combining ability through diallel matting design having eight diverse parents. The estimates of SCA variances were larger than the GCA for yield components, suggesting the pre dominance of non-additive gene action. Valarmathi et al. (2007) evaluated large number of crosses involving nine parents from 
V. unguiculata var. unguiculata and four parents of $V$. unguiculata var. sesquipedalis in Line $\mathrm{x}$ Tester matting design. The parents belonging to $V$. unguiculata var. unguiculata namely GP1024, GP1238 and GP739 and Vaijayanthi and VS33 of $V$. unguiculata var. sesquipedalis were good combiners for green pod yield. Ushakumari et al. (2010) analyzed heterosis and combining ability in line $\mathrm{x}$ tester matting design using five lines and five testers. The results reveled that the parents viz. TC 49-1, Lola, Sarika, VBN1, CO2 and CO (CP) 7 were observed as good general combiners for seed yield. Similarly, the parents viz. TC 49-1, Lola and VBN1 were found good general combiners for characters such as days to $50 \%$ flowering, plant height, cluster per plant, pods per plant, pod length and number of seeds per pod. Among the hybrid combinations, the crosses Lola $x$ VBN 1, Sarika x VBN 1 and Sarika x CO (CP) 7 were the best specific combiners for grain yield. Tchiagam et al. (2011) undertook a study at Dang (soudano-guinean zone of Cameroon) to determine the variability of 100 -seed weight, geometric surface, porosity and sphericity of the seeds of 10 cowpea (Vigna unguiculata) genotypes and investigate the genetic basis of these characters through a $5 \times 5$ half-diallel mating design. The analysis demonstrated that the parents differed for their GCA and the crosses showed SCA effects. These physical parameters were highly heritable with broad-sense heritability (hÂ $\hat{A}^{2}$ values ranged from 0.76 to 0.96 suggesting that genetic advance was expected. Both dominant and additive gene effects were significant for all traits with a predominance of additive genes for seed mass and dominant genes for degree of sphericity. Sharma et al. (2011) evaluated six lines as female parents and four testers as male parents in line $\mathrm{x}$ tester fashion. The ICP-38, ICP-42, Indira Hari and Arka Garima were good general combiner for earliness and ICP-42, ICP-54. Pusa Komal, Arka Garima and Indira Han for green pod yield per plant. The cross combinations ICP42 x Arka Garima, ICP-54 x Indira Hari, ICP$26 \times$ Khalleshwari and ICP-49 x Khalleshwari were found the best combiners for number of pods per plant whereas, crosses ICP-42 x Arka Garima, ICP-42 x Indira Hari and ICP-54 x Arka Garima showed high significant and positive sca effects with high mean for green pod yield per plant. Daniel and Joseph (2013) conducted a diallel study involving 8 genomic cowpea cultivars from diverse geographical origin to identify superior germplasm and develop high yielding varieties. General and specific combining abilities effect were highly significant $(\mathrm{P}<0.05)$ for all the traits except for grain yield and plant height (GCA). Most of the traits had dominance gene effects. The study of GCA and SCA revealed that cultivars viz. Ekp-br, 325, ILCA-12648, ILCA-12646 were good general combiners for most of the yield attributes and can be included in future improvement programmes. Patel et al. (2013) carried out a study in half diallel matting design with 12 parents in cowpea. The parents GC- 4 and Re - 101 were the good general combiners for seed yield per plant and most of the traits. Among the crosses, the hybrids viz. CPD-103 x Re-79 followed by GC-4 x CPD105 and Rev-7 x Re-79 were the best specific combiners for seed yield per plant along with high mean performance. These hybrid combinations need to be explored by isolating 
transgressive segregants from the segregating population of these crosses. Sharma et al. (2013) found that ICP-42, ICP-45, Pusa Komal, Arka Garima and Indira Hari were good general combiners for pod length and pod weight. ICP-42, Arka Garima and Khalleshwari were good general combiners for number of pods per cluster whereas, ICP38 and ICP-54 for number of pods per plant. The crosses ICP- 42 x Indira Hari, ICP-26 x Khalleshwari, ICP-42 x Indira Hari and ICP$42 \times$ Arka Garima were identified as best specific combiners for yield contributing characters. Ayo-Vaughan et al. (2013) evaluated eight parents and their twenty-eight crosses made in diallel crossing design. The mean square differences among the parents and their hybrids for different traits were observed highly significant. The estimates of general combining ability (GCA) were larger than the specific combining ability effects for all the traits analyzed. The ratio $\mathrm{h} 2 / \mathrm{H} 2$ revealed different number of genes controlling the traits, pointing out their polygenic inherited control. The estimated low narrow sense heritability recorded in this study indicated that recurrent selection procedure could be effective to improve the analyzed traits in the genotypes included in this study. The parent Kananado with high, positive and significant GCA effects was found the best general combiner with desirable genes for the genetic improvement of the considered yield component in cowpea. Okunlola (2014) conducted an experiment in 2013 at the College of Plant Science Screen House, FUNAAB. Best combiners for plant height were crosses P2 x P3 and P1 x P3, while the best combiners for number of days to first flowering was cross $\mathrm{P} 2 \times \mathrm{P} 3$. Crosses $\mathrm{P} 1 \times \mathrm{P} 3$ and P3 x P1 were the best combiners for pod length. Crosses P1 x P3, P3 x P1 and P1 x P2 were best combiners for number of seed per pod while crosses P2 x P3 and P3 x P2 were best combiners for hundred seed weight. Generally, P2 (Ife Brown) and P3 (TVu 6198) performed better than P1 (Ife Brown Crinkled) for yields and related characters.

Selvakumar et al. (2014) carried out a study to estimate combining ability effects among crosses derived from eleven selected cowpea genotypes. The study revealed the presence of both additive and non-additive genetic components of variation for most of the characters. Based on the GCA effects, the parents GC 3, RC 101, Vyjayanthi and Vellayani jyothica were found the good general combiners. Based on SCA effects. the hybrid combinations viz. GC 3 x Vellayani local, GC 3 x Vellayani jyothica, ACM 0507 x VBN 2, ACM 05-07 x Vyjayanthi, RC 101 x Vellayani jyothica and ACM 05-02 $\mathrm{x}$ Vyjayanthi were found the best specific combiners for yield and the components associated with yield.

Gudadhe et al. (2017) carried out the combining ability analysis in cowpea diallel set (without reciprocals) for pod yield and its components. The study revealed the dominance of additive gene action for the heritability of all the traits examined. The significant GCA effects showed that the parents viz. Chikhali Local and Kashi Kanchan were good general combiners for pod yield and its attributing characters. Among hybrids, Chikahli Local $x$ Pusa Phalguni, Gadchiroli 4 x GADCP 3 and Chikhali Local $x$ Pusa Komal were the best 
specific combiners for pod yield per plant and most of the superior hybrids had high $\mathrm{x}$ low general combiners. Kumar et al. (2017) crossed eight diverse cowpea genotypes to estimate the combining ability of parents and their crosses. The study revealed that both additive and non-additive gene was responsible for inheritance of the plant growth, flowering and yield components. Out of eight parents, MFC-09-12 and UPC-9202 were found the good general combiner for days to $50 \%$ flowering, days to maturity, pods per plant and seed yield/plant. The significant SCA effects showed that the crosses, SWAD $\times$ UPC-9202 was the best specific combiner for yield and its components, while UPC-8705 $\times$ BL-2 was the best for maturity related traits. Wankhade \& Manjare (2017) carried out a study to estimate the combining ability of the parents and hybrids of cowpea in lines $\mathrm{x}$ tester fashion. The significant GCA effects revealed that the parents, C-152 and Wali 4 were good general combiner for yield contributing traits. The hybrid combinations, GC-3 X Wali 4 and C-152 X VCM-8 had higher SCA effects and were found the best specific combiners for yield contributing traits. The study also indicated the dominance of non-additive genetic component of variance for most of the traits as the variances of SCA effects were greater in magnitude than GCA effects. Priya et al. (2018) studied combining ability in cowpea for yield and its contributing attributes in Line $\times$ Tester fashion having ten parents and their twenty-four hybrids. The study showed that the non-additive component of genetic variance was dominant for all the characters studied as the estimates of SCA effects were greater than GCA effects. The parent VBN 2 was found the best general combiner among the lines for pods per plant, number of seeds per pod, hundred seed weight, protein content and pod yield per plant. Among the testers, the parent VCP-09019 was found the best general combiner for plant height, pod length and pod yield per plant. The hybrid combinations VBN $1 \times$ VCP-09-013 and CO $6 \times$ VCP-09-024 were the best specific combiners for yield and its components with significant SCA effects. Owusu et al. (2018) studied the combining ability, character association for grain yield and other traits in cowpea in a diallel crossing fashion involving 25 parents. The study revealed that both additive and non-additive gene actions were responsible for inheritance of traits studies. The characters such as grain yield, plant height, seeds per pod, pod weight and days to $50 \%$ flowering had non-additive genetic variance, while the characters like days to maturity and pod length had additive genetic variance. Parents PADI-TUYA and IT86D-610 had significant GCA effects for grain yield and other traits in desirable direction, whereas the hybrids viz. IT86D-610 $\times$ PADI-TUYA, SONGOTRA $\times$ PADI-TUYA and IT86D-610 $\times$ SARC 57-2 were observed the best specific combiners for grain yield and its components. Pallavi et al. (2018) conducted a study to estimate the combining ability in seven parents of cowpea in diallel fashion (without reciprocals) for yield and its components. The study based on the significance of GCA and SCA effects revealed that the both additive and non-additive gene actions were involved for inheritance of the traits studied. Parent viz. Pant Lobia-5 was good general combiner for plant height, green 
pod yield/plant, seed yield/ha, 100-seed weight and seed yield per plant. Based on significant SCA effects, the crosses viz. Pant Lobia-5 x Pant Lobia-2, Pant Lobia-5 x Pant Lobia-3, PVCP-20 x PCGP-59, Pant Lobia-2 $x$ Pant Lobia-1 and PGCP-63 X PGCP-53 were found the best specific combiners for yield and its components. Pethe et al. (2018) carried out an experiment involving eight lines and three testers and their 24 hybrids in line $\mathrm{X}$ tester fashion and reported the dominance of non-additive genetic component of variance for all the traits studied. The parent, CPD-83 among lines and GS- 9240 among tester were the best general combiners for majority of the yield components including grain yield per plant. The crosses viz. (CPD -83 X PCP97102), (CPD -31 X GS-9240) and (CPD -219 $X$ GS-9240) were found the best specific combiners for grain yield per plant. The characters like pod length, number of seeds per pod and harvest index recorded high heritability. Bala et al. (2018) studied the gene action and combining ability in cowpea involving eight parents and fifteen hybrids in line $\mathrm{x}$ tester matting design. The study showed that the estimates of SCA variances were higher than the GCA variances, suggesting the preponderance of non-additive genetic component of variance for all the traits studied except for days to maturity, dry matter content and protein content. The parents MFC-09-12, MFC-08-14 and PL-3 were found the good general combiners based on significant GCA effects. The crosses MFC-09-12 × PGCP-12 and MFC-08-14 $\times$ PL-3 were the best specific combiners for green fodder and grain yield and its components. Verma et al. (2019) carried out a study to understand the gene action governing pod yield and its contributing traits in cowpea and to determine the combining ability of parents and hybrids. The study showed that both additive and nonadditive gene actions were responsible for the inheritance of these traits. The parents viz. 2014/COPBVAR-4, 2012/COPBVAR-2 and 2014/COPBVAR-5 were found good general combiners for the traits such as flowers per cluster, pods per cluster, per cent pod set, pods per plant and days to last harvest. Similarly, 2014/COPBVAR-5，2012/COPBVAR-2 and Kashi Kanchan were good for green pod yield per plant. The cross combinations viz. 2014/COPBVAR-5 x Gomti, 2012/COPBVAR-3 x Pusa Komal and 2012/COPBVAR-5 x Pusa Komal were reported the best specific combiners for green pod yield per plant and other yield components. Owusu et al. (2020) carried out a study to estimate the gene action and combining ability for maturity traits and yield components in cowpea in diallel fashion. The study revealed that days to $90 \%$ pod maturity, plant height at maturity and 100-seed weight had high significant GCA effects suggesting the dominance of additive genetic component of variance for heritability of these characters. The parents Padi-Tuya, Songotra, and IT86D610 were good general combiners for grain yield, while Sanzi-Nya was good general combiner for early maturity. The hybrid combinations, Songotra $\times$ Sanzi-Nya, SARC1-57-2 $\times$ IT86D-610, Songotra $\times$ SARC-1-572 , and Padi-Tuya $\times$ Songotra recorded the high significant SCA effects for days to $50 \%$ flowering, pod length, pods per plant, pod yield, grain yield and seeds per pod in desirable direction. 


\section{Conclusion}

The information of gene action governing the particular trait is very important and helpful to a plant breeder to choose the most suitable parents for hybridization, the estimation of some other genetic parameters and choice of breeding procedures for the genetic improvement of various quantitative characters. In an autogamous crop exploitation of non-additive genetic variance as such would be impractical. Since, the research investigation exhibited that earliness and yield attributing traits were predominantly controlled by additive gene effects, simple selection procedure like single seed descent would be effective for isolating short duration progenies in advanced generations. Simple progeny selection may be followed for selecting transgressive segregants in later generations for developing genotypes having long pods. The hybrid combinations having poor $\mathrm{x}$ poor, good $\mathrm{x}$ good and poor $\mathrm{x}$ good general combining parents with high significant SCA effects may be obtained for various horticultural traits. The hybrid combinations involving both the parents as poor general combiners may have dominance $\mathrm{x}$ dominance or epistatic gene interaction and the possibility to obtain good transgressive segregants in later generation becomes low. The hybrid combinations having good $\mathrm{x}$ good general combiners with high SCA effects have great potential to develop high yielding varieties/genotypes and to give good transgressive segregants in segregating generation. Based on the nature and magnitude of gene action, systematic research approach and breeding programme is needed to develop improved varieties of cowpea with short duration, photo-thermo insensitivity, pest-disease and drought tolerance for wider adaptability and higher productivity.

\section{References}

Anonymous. 2018. Horticulture Statistics at a Glance. Horticulture Statistics Division, Department of Agriculture, Cooperation \& Farmers' Welfare, Ministry of Agriculture \& Farmers' Welfare, Government of India

Ayo-Vaughan MA, Johnson Ariyo O \& Olusanya Alake C. 2013. Combining ability and genetic components for pod and seed traits in cowpea lines. Italian Journal of Agronomy, 8(2), e10.

Bala DR, Sridhar K, Kumar V, Kulkarni NS and Sahay G. 2018. Combining ability analysis to identify dual purpose genotypes in cowpea. Range Management and Agroforestry, 39(2): 175-181.

Balai RC, Meena LR \& Sharma SC. 2017. Effect of different levels of nitrogen and phosphorus on cowpea [Vigna unguiculata (L.) Walp] under rainfed conditions of Rajasthan. Journal of Agriculture and Ecology, 3: 19-24.

Daniel OI \& Joseph EA. 2013. Diallel analysis of six agronomic characters in vigna unguiculata genotypes. African Journal of Plant Breeding, 1(1): 001-007.

Dokashi MH \& Mohamed MF. 2003. Genetic analysis of variability in earliness and yield among five local and exotic cowpea (Vigna unguiculata (L.) Walp.) varieties. Assiut Journal of Agriculture Science, 34(5): 241-255.

Gopalan C, Rama Shastri BV \& Bala Subramanian SC. 1982. Nutritive value 
of Indian Foods. ICMR, Natt. Inst. Nutrition, Hyderabad.

Gudadhe PS, Sawant SN, Jadhav SV, Nagre

PK, Kale VS \& Sawant BN. 2017. Combining ability studies in cowpea. International Journal of Chemical Studies 5(6):1432-1435.

Kalubowila I \& Uma MS. 2006. Combining Ability Analysis Involving Land Races of Grain Cowpea (Vigna unguiculata (L.) Walp). M.Sc. Thesis, UAS, Dharwad, Dharwad, Karnataka, India.

Kempthorne O. 1957. An introduction to genetic statistics. John Wiley and Sons Inc., New York.

Kumar S, Sridhar K, Kumar V \& Kulkarni NS. 2017. Combining Ability Analysis in Dual Purpose Cowpea (Vigna Unguiculata (L.) Walp). Plant Archives, 17(2): 919-923.

Manggoel W, Uguru MI, Ndam ON \& Dasbak MA. 2012. Genetic variability, correlation and path coefficient analysis of some yield components of ten cowpea [Vigna unguiculata (L.) Walp] accessions. Journal of Plant Breeding and Crop Science, 4(5): 80-86.

Okunlola OF. 2014. Combining Abilities and Heterotic Effect on Yield and Yield Related Components in Three Cowpea Crosses. Plant Breeding and Seed Technology, Federal University of Agriculture Abeokuta.

Owusu EW, Mohammed H, Manigben KA, Adjebeng-Danquah J, Kusi F, Karikari B \& Sie EK. 2020. Diallel Analysis and Heritability of Grain Yield, Yield Components and Maturity Traits in Cowpea (Vigna unguiculata (L.) Walp.).
The Scientific World Journal. Article ID 9390287, 9 pages, https://doi.org/10.1155/2020/9390287.

Owusu EY, Amegbor IK, Darkwa K, OtengFrimpong R \& Sie EF. 2018. Gene action and combining ability studies for grain yield and its related traits in cowpea (Vigna unguiculata), Cogent Food \& Agriculture, 4: 1519973.

Pallavi Singh, YV, Verma, A \& Bansala MK. 2018. Analysis of Combining Ability for Yield and its attributing Characters in Cowpea (Vigna unguiculata (L.) Walp). Pharma Innovation, 7(7): 202-204.

Patel NB, Desai RT, Patel BN \& Koladiya PB. 2013. Combining Ability Study for Seed Yield in Cowpea [Vigna Unguiculata (L.) Walp]. The Bioscan, 8(1): 139-142.

Patel SP, Dhedhi KK, Bharodia PS \& Joshi AK. 2008. Genetic analysis of pod yield and its attributes in vegetable cowpea. Journal of Food Legumes, 21(2): 89-92.

Pethe UB, Dodiya NS, Bhave SG \& Dalvi VV. 2018. Line $x$ Tester Analysis for Combining Ability in Cowpea [Vigna unguiculata (L.) Walp]. International Journal of Current Microbiology and Applied Science, 7(01): 511-515.

Priya RD, Thangaraj K, Gnanamalar RP \& Senthil N. 2018. Combining ability studies for grain yield and its component traits in cowpea (Vigna unguiculata (L.) Walp) Electronic Journal of Plant Breeding, 9 (3): 941-947.

Samadia DK \& Haldhar SM. 2019. Scope and strategies for genetic improvement in vegetable crop-plants under high temperature and abiotic stressed climate 
of Rajasthan: A gap analysis. Journal of Agriculture and Ecology, 8: 1-18.

Selvakumar G, Anandakumar CR, Chinniah C. \& Ushakumari R. 2014. Combining ability analysis in the inter sub specific crosses of cowpea (Vigna unguiculata (L.) Walp) and yard long bean (Vigna unguiculata (L.) spp. sesquipedalis). Electronic Journal of Plant Breeding, 5(2): 187-191.

Sharma D, Mehta N, Trivedi J \& Gupta CR. 2011. Combining ability anatysis for green pod yield and its components in inter sub-species of cowpea Vigna unguiculata (L) Walp. ssp. Vegetable Science, 38(2): 156-162.

Sharma D, Mehta N, Singh J \& Gupta CR. 2013. Genetic study for some pod characters in vegetable cowpea (Vigna unguiculata (L.) Walp.). Vegetable Science, 40(1): 73-76.

Shashibhushan D \& Chaudhari FP. 2000. Selection of superior combiners in cowpea. Crop Research, 20(2): 268-273.

Singh I, Badaya SN \& Tikka SBS. 2006.

Combining ability for yield over environments in cowpea (Vigna unguiculata (L.) Walp.). Indian Journal of Crop Science, 1(1-2): 205-206.

Singh SP, Kumar R, Joshi AK \& Singh B. 2004. Genetic architecture of yield traits in cowpea [Vigna unguiculata (L.) Walp.]. Advances in Plant Sciences, 17(2): 495-502.

Steele WM. 1976. Cowpeas. In: Evolution of crop plants (Simmonds, N.W.) Ed. Longman, London pp.183-185.

Thiagarajan K \& Rajasekaran S. 1989. Genotypes x environment interaction for grain yield in cowpea. Madras Agriculture Journal, 74: 15-17.

Thiagarajan K \& Natarajan C. 1989. Genetic divergence in cowpea. Tropical Grain Legume Bulletin, 2-3.

Noubissie TJB, Bell JM, Ngakeu FD, Njintang YN \& Youmbi E. 2011. Diallel analysis of cowpea (Vigna unguiculata (L.) Walp.) for some physical properties of seed under the Sudano-guinean conditions. Agriculture \& Biology Journal of North America, 2(4): 698707.

Ushakumari R, Vairam N, Anandakumar CR \& Malini N. 2010. Studies on hybrid vigour and combining ability for seed yield and contributing characters in cowpea (Vigna unguiculata). Electronic Journal of Plant Breeding, 1(4): 940947.

Valarmathi G, Surendran C \& Muthaih AR. 2007. Studies on combining ability for yield and yield traits in inter subspecies crosses of cowpea (Vigna unguiculata ssp. unguiculata and Vigna unguiculata ssp. sesquipedalis). Legume Research, 30(3): 173-179.

Vavilov NI. 1939. Chromosome Atlas of cultivated plants. George Allen Unwin Ltd., London.

Verma AK, Mehta AK, Sharma D \& Singh RP. 2019. Genetic analysis of pod yield and its contributing traits in cowpea (Vigna unguiculata L. Walp). International Journal of Chemical Studies, 8(1): 965-970.

Wankhade MP \& Manjare MR. 2016. Combining ability and gene action studies in cowpea (Vigna unguiculata (L.) Walp). Vegetable Science, 43(2) 198-201. 